\author{
稀有ナル遊走脾ノ一例 \\ 望マリアンナ研究所 (顧問 飯塚直彦博士, 所長 小河原四郎博士) \\ 明 石 嘉 聞 \\ 聖マリアンナ會東橫病院胃腸科 \\ 明 石 憲 男 \\ 聖マソアンナ會東橫病院外科 \\ 加 藤 守 正
}

\title{
I 緒咅
}

胃腸障碍及ビ月經異常 伴ナイタル稀有ナル避走脾ノ一例 7 體驗シタノデ，茲二報告スル。

\section{II 臨 床例}

保○喜○子. 37歲. 經発婦.

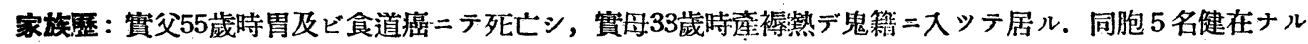
モ胃弱ノ者多シト言ウ。

生活史：22歲時結婚, 大速二テ約13年盟過ゴシ終戰後內地ニ引キ揚ゲタ. 子女 5 名 (ㅇ15歳, 13歲, 今11歲, 8 歳, 5 歲) 何レモ健在デアル.

既往症：生來虛弱, 初經14年 7 ケ月デアラワレ, 爾來月經不順, 時二困難ノコトモアッタガ, 結婚後輕快 シ殆ド苦痛シ感ジナクナッタト言ウ.17歲時慢性副鼻腔炎ニテ手術 初冬等二發作アリト言ウ。

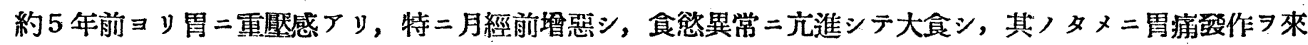
スろレドモ，月經終了ト同時二前記胃症狀ワ全ク消腿シ，每月此ノ症狀 觀念ガ來ルヨウニナッタ.

現病属：本年7月6日胃腸科外來 アッタ. 胃痛ハ單二壓重感程度ノ事モアリ叒刺痛樣ノコトモアルガ接續的デ此ノ時分ョリ心留部ノ腄瘤二氣 ガッイタト言ウ. 外來治潦ニヨリ胃腸症狀入輕快シ食㗹モ出テ來タガ, 腫瘤ハ依然トシテ，心瓷部二觸知サ レ, 特ニ月經前二畽大ノ傾向アリ，月經終了後八縮少シテ觸知サレザルコトモアッタ. 臨床診斷トシテ第一 二胃癌习疑イ入院 7 獎メタガ以後 9 月汽患诸ワ誩㿟ニ來テイナイ.

現症：9月4日胃痛發作激ショ，頻回ノ湢吐アリ心部部腫瘤大トナリタリトテス院シタ（月經豫定日ワ9月 12日ナりト).

入院時所見ワ次ノ如クデアル。

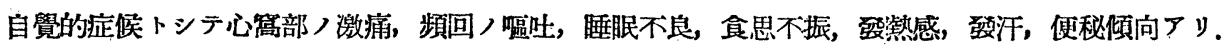

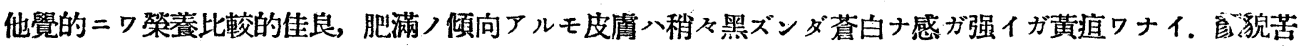

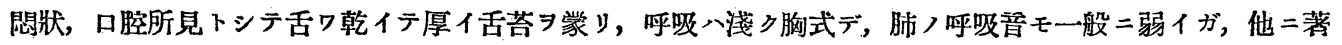
變ワナイ、肺肝境界ワV助間デ肺移動モ良好デアン，肝臟ワ觸知サレナイ。

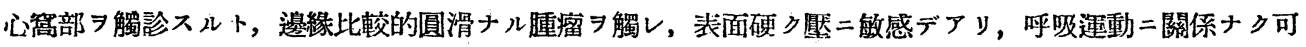

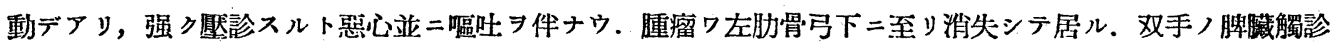

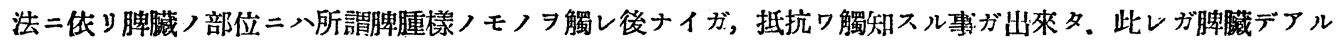

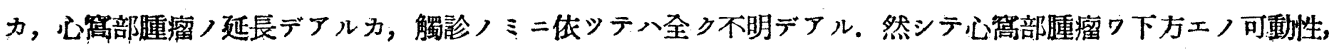


前後ノ移動性ワ認メラレルガ, 左方エ入觸診二体ツテワ移動シナイ. 敢エテ移動セシメョシトスレバ，激烈

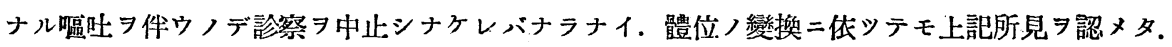

同日直チニれんとげん透視 $コ$ 實施セルニ, ばりらむワ胃泡ノ右側二一時帶留シ，體部ニ流入シテ全盈後モ 少量殘留スル。噴門部ヨリ胃小彎部ニカケテ, 相當大ナル陰影ノ欠損ガ判然ト認メラレ, 該部ノ檿痛誠二藷明 デアッテ明ラカ二腫瘤习觸知シタ. 腫瘤ノタメニ, 下行結腸ワ右下方二區迫サレテ居ル。然シ乍ラ胃體部， 粘膜れりーふ像ワ正シク平滑デ, 粗大, 萎縮, 偏寄, 放線狀詡集等, 傢ワナイ. 左季肋下二比較的透明ナ空 氣像トハ異ナリタル傢习認メルガ, 之ガ脾腫カ又ワ前記腫瘤ト關倸ガアルカワ判然トシナイ. 胃ワ鈎型ニシ テ, 高度二下垂シ, 緊張ワ梢及低下シテ居ルァレドモ, 幽門部, 十二指腸球部ニワ特記スベキ變化ワナク, 通過性モ正常デアル. 以上X線透悓所見ノミニ訨シテハ膵贜囊腫, 脾腫ガ疑ワレル. 然シ癌腫モ亦否定出來 ナイ所見デアル。

血液所見トシテハ白血球 7100 , 赤血球 $413 \times 104$, 血色素 $62 \%$ \%゙，血液像二於テワ淋巴球增加）傾向 $(36 \%$ ） ニアルガ, 他ニ大ナル變化ワナイ.

尿所見トシテ䗎，蛋白共二陰性デアルガ，万ろびりん，5ろびりのーげん，共二陽性デアル。 かふいん法二依儿胃液所見トシテ，遊離監酸80分迄上昇スルガ, 最高 52 デアり總酸度モ亦 120 デ58デアッテ 無酸症乃至, 減酸症デモナイ。

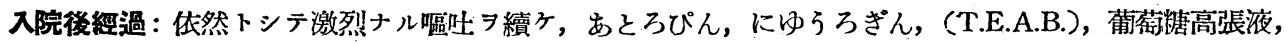
はいぼん等二依り一時的小康ワ得ラレルガ腫瘤ワ增大ノ傾向习辿り，9月12日二至り，豫定ノ如ク月經來潮

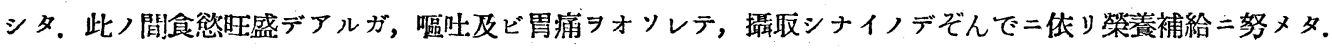
月經來潮卜同時二, 心䣉部腫瘤ワ縮少/傾向ヨトルガ, 深部二抵抗トシテ觸知サレル。カクシテ胃痛及ビ 嘔吐ワ去り胃症狀ワ著シク筧解スルニ至ツタ，唯心简部ノ不快感下腹部ノ輕イ膨滿感ガ残ツテ居ル。

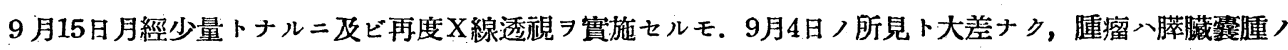
疑イシ主トシ，溜腫，脾腫等モ否定出來ザルマ、診斷ノタメ外科エ轉科セジタ.

手科所見: 9 月18日月經終了後開腹手術习賽施シタ。ペるかみん=依儿高位腰椎麻醉ノ下二, 上腹部正中 切開二体り腹腔

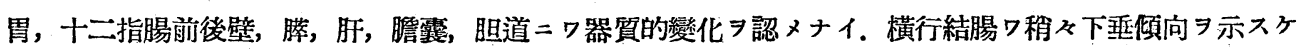
レドモ,とらいつ帶部ノ異常涾着ワナイ。

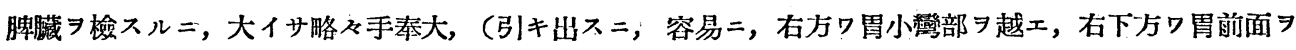
覆ウテ, 自由二移動シ索出スルコトガ可能デアル。即千觸診上心窝部腫瘤ワ此/遊走性脾臟ナルコトガ判明 シ夕。

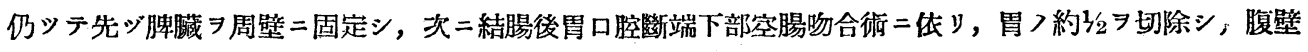

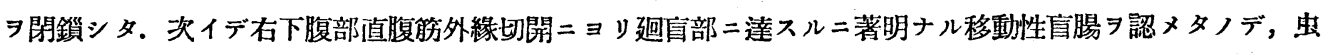
琶切除卜共二盲腸綘縮固定術 $コ$ 施シテ, 術

9 月26日創治㽷シ一般症狀輕快セルニ体り胃腸科エ復歸シタ. 當時輕度ノ喘息發作アリ治潦ヨ繼續シ術後 21日ニシテ全治退院シタ.

\section{II考按並ビニ結語}

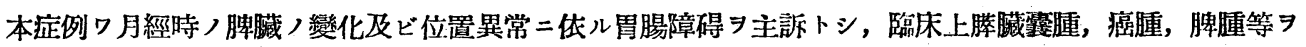
疑ワシメ手術ノ結果, 遊走脾习確メ得タル稀有ナル一例デアル。

胃下垂症二依り肝胃靶帶, 脾胃勒帶, 横隔膜勒帶八弛綏ニョル遊走脾ヨ來シタルモノデアッテ, 胃ノ下垂

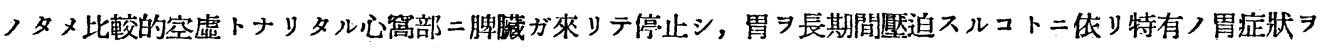
登現セルモノト考エラル，頑固ナル琹心，澏叶等ノ神經症發現モ首肯セラル、所デアル。 


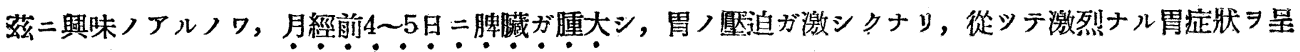
シ, 月經終了後脾臓ノ縮小ト共二, 諸症狀ノ寬解スルコトデアル。

斯ル症狀 ギタイ.

擱筆スルニ當り京都府立醫科大學名譽敉授饭塚直斈博士ノ御校閲

明石嘉・明石憲・加藤論交附圖

(1)

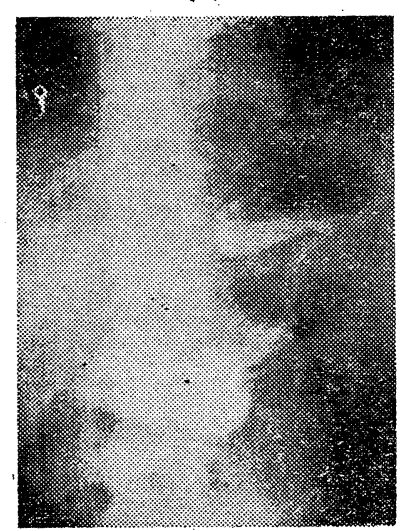

游走脾X線所見 (1)
(2)

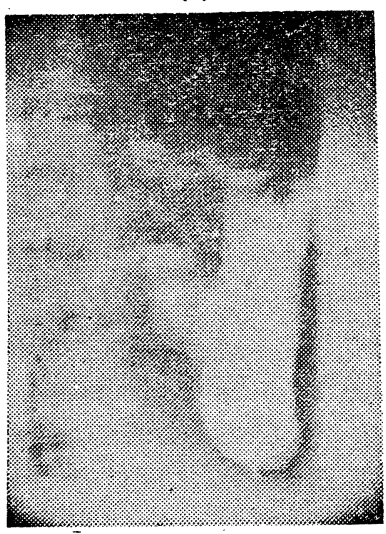

遊走脾 X線所見 (2) 


\title{
A Rare Case of the Mobile Spleen.
}

By

\author{
Dr. Kamon AKaSHI
}

St. Marianna Society Research Institute (Advisor: Dr. Naohiko Iizuka

Director: Dr. Shiro Ogawara)

\section{Dr. Norio AKashi}

St. Marianna Society, Toyoko Hospital Digestive Diseases Department

\section{Dr. Morimasa KATo}

\section{St. Marianna Society, Toyoko Hospital Surgery Department}

1) When an examination was made of a 37 year-old married out.patient, who complained chiefly of severe vomiting and stomach colic and who had a tumour in her epigastrium, she was first suspected of having cancer of the stomach. Her father had died of the cancer disease.

2) Following an X-ray inspection, the large tumour in the hind wall of the stomach was believed to be a pancreas tumour or a dilatation of the spleen, but cancer of the stomach could not be ruled out altogether.

3) Observation of the blood showed a relatively lymphocytose condition (36\%), and anaemic and other changes could not be recognized.

Both Wasserman's and Kahn's reactions were negtive.

4) Observation of the gastric juices indicated that the patient had relatively low acidity, but was not acidless.

Aside from small quantities of urobilin add urobilinogen appearing in the urine, no other changes were evidenced.

5) The tumour became enlarged prior to menstruation, resulting in increased severness of the stomach symptoms, but as a rule, all the symptoms became light as soon as menstruation stopped.

6) Upon performing laparatomie, the tumour was fond to be the mobile spleen resulting from advance slackness of ligamentum hepatogastrium, ligamentum gastrolienale and ligamentum phrenicolicun due to stomach ptosis.

7) An operation was performed in weich one-half of the stomach was removed together with an operation to immobilize the spleen as well as the appendix.

Three weeks later the patient was discharged in a healthy condition. 